\title{
Moroccan Traditional Songs Based on Stereotypes of Mothers in Law and Daughters in Law and Their Impact on Family Life
}

\author{
Touria Houssam*, Fouzia Lamkhanter \\ Hassan II University Casablanca, Morocco
}

Copyright $(2016$ by authors, all rights reserved. Authors agree that this article remains permanently open access under the terms of the Creative Commons Attribution License 4.0 International License

\begin{abstract}
This research paper relates to a sociolinguistic study of Moroccan traditional lyrics that reflect the sensitive nature of the mother/daughter-in-law relationship. These lyrics produced and presented vividly in Moroccan traditional songs tend to create antagonism and conflict to Moroccan families. The data consist of recordings of some popular songs entertained in rural areas by ordinary women. We will shed light on the importance of oral tradition as a means of transmission of collective imagination and production of stereotypes and social representations. These representations and stereotypes are very dominant in the Moroccan oral tradition and continuously contribute to the maintenance of inequality and gender discrimination. We will scrutinize the connotations conveyed in these folk songs to be able to describe, analyze and subsequently enumerate the different stereotypes that this corpus reveals. The information gathered in this study up to now, as well as others, reveal the existence of different stereotypes associated with the status of both, the mother-in-law and the daughter-in-law. It also describes the tense and confrontational nature of the relationship between the two women, a thing that seems inevitable. The nature of the relationship that these songs cause and tend to impart, consciously or/and unconsciously, influences family relationships. The Moroccan family lives under the weight of these representations that feed tensions, disrupt family life and consequently feed moments of domination, power struggle and even moments of crisis. Indeed, the Stereotypes linked to this relationship mother-in-law/ daughter-in-law represent real cultural challenges for family life. All in all, we will highlight, on the basis of an extended corpus of popular songs the colorful relationship between the mother-in-law and the daughter-in-law through analyzing the relevance of these stereotypes and social representations as well as their impact on the Moroccan family.
\end{abstract}

Keywords Language, Culture, Gender, Mother-in-law, Daughter-in-law, Traditional Songs, Family Relations

\section{Introduction}

Oral tradition has always been important in all cultures. The latters are inherited and transmitted by word of mouth. Indeed, this is the heritage we bequeath our ancestors, all our day-to-day knowledge and practices which are related to the survival and reproduction of all the social imagination. It has an adaptive aspect that helps generations to identify, confirm and blend into the community. This knowledge is acquired by hearsay without losing time fumbling to find out everything on our own. It is also a very rich database that is orally transmitted from one generation to another.

In case this knowledge transmitted is discriminatory as is the case in discriminations linked to gender, oral tradition would be a way that strengthens and perpetuates unequally and arbitrarily constructed representations and which have negatively influenced behavior towards each other.

Oral tradition has several components including: tales, fables, myths, epics, genealogies, proverbs, riddles, puzzles and songs. In Morocco, they are all full of gender stereotypes and ensure the existence and the transmission of power relations together with the restoration of the patriarchal order by women themselves as is the case of pleasant singing we have been attracted by. These are songs that women sing for fun when they get together for a party or for a simple event. They convey much sense and are very well sung by women without musical instruments and with harmonious rhythms. We listened with interest to the women who received us in Douar in the region of Elbrouj about $150 \mathrm{~km}$ southeast of the city of Casablanca. Their lyrics are pleasant, rich of stereotypes and full of connotations. This interest has only confirmed our choice to make these pleasant folk songs our data of work so as to reveal these different cultural connotations and stereotypes.

\section{Language and Culture}

Chadiha, Miller, Cribbs, and Wilson Klav (1997), in 
Webb [15] define culture as the "learned knowledge, beliefs, arts, morals, laws, and customs of the members of a society." They believe that" it encompasses the world view, thoughts, behaviours, and communication patterns of persons affiliated with the culture."

Culture then is a set of common practices, ways of thinking and looking at things which make a number of people an entity. It is the way that helps them map the meaning of things around them and develop, in this way, distinct patterns of life, since experience differs from one group to another and from one individual to another. Kramsch [8] puts it clearly when he says that speakers from different cultural backgrounds may have "different interpretations of what it means to be true, relevant, brief, or clear with regard to conversations". The same opinion is noted in Hall (1997) in Barker and Galasinski [1]; he states that culture depends on its participants' interpreting meaningfully what is happening around them, and making sense of the world in broadly similar ways. Culture, then, helps people develop a specific look at life around, and it is this common perception that makes of them an entity. Rocher [14] adds the notion of learning explicitly. He states that culture is "a related whole of more or less formalized ways of thinking, feeling, and acting which, learnt and shared by a number of people, serve both objectively and symbolically, to make of those people a special, distinct collectivity".

Now comes time to ask the question about the relationship between culture and language. Given that language is a means of communication and a symbol of group identity, it follows that it incarnates the culture of its particular speakers. Indeed, culture is "acquired, socially transmitted, and communicated in large by language,"Grosjean [17]. Malinowsky [10] and Firth [4] state that knowing a language involves much more than knowing just the structure or the meaning of the expressions, especially in the context of situation and context of culture. Fishman [5] reduces the intricate relationship between language and culture to three major types:

First, "at any given point in time, every language indexes its associated culture more fully than others do. The distinctive conventions, concern, values, and beliefs of any culture are more fully, easily and naturally expressed by its associated language than others. Even the most accomplished and elaborate languages are suddenly inelegant, imprecise, unnatural and finally even ludicrous when put to the unfair task of expressing the nuances of a culture which they have not been intimately identified" Fishman [5]. In other words, there exist many cultural notions that cannot be expressed properly except through their associated language.

Second, Fishman [5] adds that "at any given point in time, every language symbolizes its associated culture more fully than others do". The language in this sense represents and guarantees the existence of the culture. It is left to test whether there have been ways to secure the inter-generational, cultural continuity
Third, Fishman [5] believes that "at any given point in time, every language enacts its associated culture more fully than others do. A language not only indexes and symbolizes its associated culture but it is part and parcel of that culture." From law and religion to songs, tales, riddles and everyday greetings, every culture is 'language specific'.

All in all, "cultures are not simple adornment any more than languages are mere tools of communication. Both tell individuals what the world is made of, and how to act upon it," Larrivée [13].

In our study, traditional songs reflect the cultural beliefs/ stereotypes that are linked to the mother-in-law and daughter-in-law relationship. Universally, the relationship between mother-in-law/daughter-in-law is characterized by conflict. Conflicts between them oscillate between power issues and rivalries. The mother-in-law being jealous keeps a close watch on the newcomer so that she cannot impinge on her powers of "domestic" matriarch (Ducloux, [3]) and that she would not have a great place in the heart of her husband at the expense of his love for his mother. The couple only worthwhile, therefore, appears to be that of Mother/Son. This is a context in which the couple Husband/ Wife "is irrelevant and not welcomed." The mother-in-law believes that she is protecting the interests of her son because her daughter-in-law is not "good enough" (Winnicott, [16]). She creates permanent conflicts with her daughter-in-law and engenders problems in the couple. In fact, she is incarnating the "male domination '(Bourdieu, [2]). Instead of being exercised by the husband, this domination is practiced by the couple mother-in-law/husband (Lacoste-Dujardin, [9]). The rivalry between mother-in-law/daughter-in-law is therefore among the very recurring issues in oral traditions and is not a characteristic of our culture only.

\section{Methodology}

As for the analysis of qualitative data, we have had the choice between three methods of analysis. The first one is hypothetical/ deductive. It gives primacy to theory and is mainly concerned with developing hypotheses from existing theories before having recourse to fieldwork so as to validate or refute these hypotheses. The second method is an inductive one. It gives primacy to fieldwork and then develops the theory. The third method, the Grounded Theory, is the one we have adopted for our analysis. It is based on a back-and-forth between fieldwork and theory. This method starts from fieldwork to develop the first hypotheses. Then, it requires several returns to the field to reorient the approach and refine the assumptions for a better theoretical construction.

The methodology of this research was based on the grounded theories whose principles allow the empirical approach to qualitative data and permit its inductive analysis. Equally, the reliance of the grounded theory on the continuous and progressive questioning of the data gathered throughout analysis results in a better understanding of the 
phenomenon studied. The search for informants who are willing and have knowledge of popular songs was done initially in the urban sector. The purpose was to look for old women who had kept this oral tradition. This trial to gather data in the urban and the peripheral zone of cities was without any concrete results. We then went to the region of elbrouj since this region is known by its folk pleasant songs that women repeat when they are together.

A first exploratory visit to Douar Ouled to Elqorchi in the region of Elbrouj village, about $150 \mathrm{~km}$ southeast of the city of Casablanca, was mainly done in April 2008. It was meant to listen to these songs and examine the most important elements. During the two other visits to this Douar, the interest to this predominant theme in folk songs, that of the mother-in-law's relationship with her daughter-in-law was raised gradually. Among the various recorded songs, the choice has been made on five songs that have served as a corpus for this search. We have discarded two songs because they do not speak about the relationship mother-in-law/ daughter-in-law. These songs are sung by seven rural women whose ages range between 54 and 73 and who belong to different families in the region of Elbrouj. The choice of the informants was done depending on their availabilities and their acquaintance to a member of our family who lives in the same area. The analysis of the data collected has respected the steps of the grounded theory.

\section{Analysis, Discussion and Findings}

The data we have relied on in this study consists of five songs whose themes tackle either the different representations attached to the mother and the mother-in-law or the rivalry between mother-in-law and daughter-in-law. The first song revolves around a wife who addresses her husband without calling him by his name. She calls him son of the enemy. She associates the arrival of his mother to a desire to sow disagreement, discord and disharmony between her and her husband and wishes him the bite of a viper. To her mother, she prepares food and describes her as the poor, the mediator, the protector and the reconciler.

The second song is a dialogue between the daughter-in-law and the mother. It clearly shows their rival relationship. These are real insults that the two women exchange using clear and direct words.

In the third song the wife requests looking for her mother, who is tender, generous and who is willing to take risks for her daughters. She does not appreciate the arrival of her mother-in-law which is a source of discord and strife.

In the fourth song the wife asks the husband to take a snake or a scorpion to his mother. She wishes her a sudden death while she asks him to bring chicken and Sugar Loaf to her mother in order to meet her needs and to remain in good health.

The fifth song is another version of the first song. The daughter-in-law is talking to her husband. She wishes her mother-in-law to be seriously ill. She describes her as the enemy everyone tends to flee.

We have relied on the gender approach to analyze our corpus. This approach allows us to account for arbitrary representations and stereotypes associated with women. These representations and stereotypes are predominant in our Moroccan oral tradition and obviously help to maintain inequalities and gender-based discriminations. We will, through this approach, try to deconstruct the pleasant connotations introduced in the songs under study in order to describe, analyze and subsequently construct the different stereotypes that this corpus refers to.

\subsection{The Representations of the wife's Mother versus the Mother-in-law}

In songs 1 and 5, the wife addresses her husband. She speaks about his mother. The wife, and to avoid calling her mother-in-law "the enemy" uses the expression son of the enemy to attenuate the insult. The arrival of the mother-in-law is undesirable. She is the enemy to avoid. She comes to cause all sorts of problems between spouses: quarrel, discord and disharmony. The relationship between the two women is full of hatred to the point that the daughter-in-law wishes the death of the mother-in-law, a sudden and rapid death by the bite of a viper being introduced into the basket.

However, when the wife speaks about her mother she uses different vocabulary, full of tenderness and admiration. A speech full of positive adjectives; her mother would be the mediator, the protector and the reconciler. She extends a warm welcome to her mother: my mother comes, the poor, I will prepare pancakes.

The same representations of the mother and the mother-in-law crop up in song 3 . The mother is introduced as generous, courageous and always ready to look after the interests of her daughters. This is the mother of the ladies who is generous and who faces danger for her daughters. Her arrival is expected everywhere and is welcomed. However, the man's mother cannot enjoy the stay at her son's because she is always looked at as a source of problems.

The data reveals the following associations:

\section{a-The tender mother}

The mother in the Moroccan culture is very close to her children; she takes care of their education and is always associated with affection, tenderness and love .Her behaviour with her children is always warm. The father, in most cases, should represent authority and therefore must keep his distance from his sons and daughters.

\section{b-The never-satisfied mother-in-law}

The stereotype of the mother-in-law is one of the strongest and most inked and engraved one in our Moroccan collective imagination. Whenever the word is pronounced, a stream of traits invades our minds. The mother-in-law cannot love or have a good emotional relationship with her daughter-in-law. She always seeks to make her life unbearable. She would 
circulate criticism and bad impressions about her. She is never pleased with her daughter-in-law's reactions.

\section{c- The rivalry among women}

In general, there exists a rivalry between women that prevents them from living in an atmosphere of sisterhood and peace. This lack of understanding between women is the result of the patriarchal mentality that is afraid of females' union which is likely to threaten its position. This is why men indirectly ensure that this conflict occurs and persists since male dominance, in the Moroccan society, is manifested by both women and men.

The representation of the mother-in-law is shaped through oral language and through the lyrics sung by women. The stereotype is automatically linked to this status once the woman becomes a mother-in-law, regardless of the good qualities that she can have. The internalization of these two stereotypes regarding the mother and the mother-in-law is reflected by the willingness of the wife to take care of her mother neglecting or even hurting her husband's mother.

In song 4: the wife enumerates different things she would like her husband to bring to his mother, namely $a$ snake and $a$ scorpion. To her own mother, he would bring chicken and Sugar Loaf. The same line of thought is kept in in song 5: your mother is here, I wish she would suffer from a serious illness, from which she would never recover. The wife expresses her wishes clearly, death for the mother-in-law and life for her mother as has been clearly stated.

\subsection{Rivalry between Mother-in-law and Daughter-in-law}

As has been illustrated in section 2, the rivalry between mother-in-law/daughter-in-law is among the very recurring issues in oral traditions and is not a characteristic of our Moroccan culture only.

In song 2, the wife and her mother-in-law are conversing and harming each other, a thing clearly apparent by the use of the two verbs, be away and push themselves. Undoubtedly, the wife does not want her mother-in-law home. She wants her to live somewhere else breaking all ties with her son mother-in-law Oh, get away! This is no longer your son. Your son, you've raised. So your share of it you had it. The mother-in-law, and despite all these insults, does not want her daughter-in-law to quit but just to be away. We can understand the use of these two different verbs, because the mother does not want to destroy the life of her son but still cannot help criticizing his wife. She describes her as a very young immature lady. The daughter-in-law expresses her determination to keep the husband without his mother using oppositions calling him sweet/ her bitter. The mother envies her daughter-in-law because she is spoiled while she does not deserve all that.

Hence, many stereotypes of the two women are constructed. The mother and the daughter-in-law are presented by the following associations:

a-The stingy mother-in-law
In our Moroccan culture, the mother-in-law is perceived as stingy. In the countryside, we sometimes have cases of some women who keep tea and sugar loaves and take care to specify the amount to be consumed to the extent that the daughter-in-law has no right to make tea without the consent of her mother-in-law. This song reflects the stereotype of the greedy mother-in-law: that continues to count the round loaves. That continues to count the coins as well.

\section{b- The problematic mother-in-law}

Neither the mother nor her daughter-in-law love or accept one another. This non-acceptance pushes the mother-in-law to have a hostile attitude towards her son's wife and to create problems in her marriage.

\section{c-The lazy/ incompetent daughter-in-law}

For the mother, her daughter-in-law is incapable and lazy: she is always lying. The act of lying is not tolerated coming from a Moroccan woman. She is supposed to always be doing the household and to respond to the stereotypes imposed by society. Things tend to change but not everywhere because such cases persist in rural areas.

\section{d-The mature mother-in-law}

The difference in age between the two women makes the mother-in-law feel superior to her daughter-in-law. There is no case of Behavior change that is expected to take place given the evolution of communities. The daughter-in-law is not a good woman since she does not breastfeed her son. This can be explained by the fact that the daughter-in-law has got small breasts which has become widespread now. Nowadays, women tend to take care of their appearance and limit the number of children. They no longer breastfeed many children and their breasts are not as big as those of women of the generation that precedes them. This is frowned upon by the mothers-in-law who, to take revenge over her by her son's wife, is described as big chest woman.

\section{e-The fragile daughter-in-law}

The same principle here applies. The fact of going to the hospital is not perceived as an evolution which reflects the improvement of the health care system in Morocco and the construction of hospitals in rural areas. This is seen as a weakness You often go to hospital and you do not breastfeed your son, go away!

\section{Conclusions}

In a nutshell, Oral tradition reflects arbitrarily founded stereotypes, and participates in the construction of a whole social imaginary that generations inherit and transmit.

Not only do popular songs have a function to please and create an atmosphere of joy and sisterhood, they also support a cultural heritage that acts consciously and/or unconsciously on the representations that people have of both mother-in-law and daughter-in-law. 
Our study has clearly shown the different ways in which the daughter-in-law looks at her mother and at her mother-in-law. The former is a source of tenderness and kindness while the latter is a source of wickedness and problems with her husband. Furthermore, the study has shown how the rivalry between the mother-in-law and the daughter-in-law pushes one and the other to build different stereotypes that are transmitted via traditional songs namely, the stereotype of the greedy mother-in-law who seeks to harm and destroy the marriage of her son, and the stereotype of the incapable, lazy and fragile daughter-in-law who is not good enough in the eyes of her mother-in-law.

Through these stereotypes, songs guarantee the stabilization of the dominant and pre-established patriarchal order that limits women in some social roles that are not to be exceeded. These women are themselves the guardians who watch over this imaginary transmission through time and space.

\section{Acknowledgements}

Both authors are thankful to the European Sociological Association 2015.

\section{Annexe}

song 1:

Your mother is coming! Oh son of the enemy, your mother is coming!

Your mother comes to spread quarrel

Your mother comes to sow discord

Your mother comes to sow misunderstanding

When my mother arrives, the poor lady, I will prepare pancakes for her

Your mother is coming, she gets a viper in her basket! Your mother is coming!

And my mother is going to come as a mediator!

And my mother is going to be a protectress!

And my mother is coming and will be the reconciler!

song 2:

Daughter in law: Go away

Oh mother in law, go away! This is no longer your son.

You have already raised your child and have already profited from his presence

Mother in law

And the daughter in law is lying down, unable to do anything. He is there to do everything, even to handle the gaz bottle

She has not breastfed her son and she often goes to hospital

Daughter in law

Go away!

Oh mother in law, be away! he is no longer your son

Go away!
Oh mother in law! get away! your turn is over.

Go away!

Oh mother in law, you have head like a bucket

She is bitter and her son is handsome

Eh mother in law with large mats that continues to count the round loaves.

Eh mother in law who has a big chest that continues to count money/pennies

You have raised your son. Get away now

Mother in law

Move over, daughter in law, move over!

You often go to hospital and you do not breastfeed your son, go away!

Song 3

Will you fetch my mother! Go and get her!

La maman des jeunes filles, qui ne fait pas de comptes

The mother of young ladies who

Oh! Will you fetch my mother! Go and get her!

The mother of young ladies who ........and who is ready to confront dangers for them

Oh will you fetch my mum

His mother has come to sow discord

His mother has come to provoke dispute.

Will you Fetch my mother! Go and get her!

\section{Song 4}

Will you take things to your mother! oh man

Put the viper in the basket and carry it to your mother.

Take that to your mum, oh man!

Will you take things to your mother! oh

Mets le scorpion dans le panier et porte-le à ta mère. Porte

à ta mère oh homme!

Put the scorpion in the basket and carry it to your mother.

Take that to your mum, oh man!

Will you take things to your mother! oh man

Put the chicken in the basket and carry it to my mother.

Take that to your mum, oh man!

Porte à ma mère. Porte à ma mère oh homme!

Will you take things to my mother! oh man

Put the sugar loaf in the basket and carry it to my mother.

Take that to your mum, oh man!

Will you take things to my mother! oh man

Put the viper in the basket and carry it to your mother.

Take that to your mum, oh man!

Will you take things to your mother!oh man

Put the scorpion in the basket and carry it to your mother.

Take that to your mum, oh man!

Will you take things to your mother! oh

Song 5

Your mother is going to come

Your mother is going to come! Oh son of the enemy

Your mother is going to come

Your mother is going to come. I wish she would suffer

from a serious illness she would never recover from!

Your mother is going to come 
Your mother is going to come! Oh son of the enemy People generally flee enemies I have got to be close Your mother, oh son of the enemy! Your mother, oh son of the enemy!

\section{REFERENCES}

[1] Barker, C., \& Galasinski, D. (2001). Chapter 3: Tools for Discourse Analysis. Cultural Studies and Discourse Analysis: A Dialogue on Language and Identity, 62-85.

[2] Bourdieu, P. (1998). La domination masculine, Editions du Seuil.

[3] Ducloux, A. (2009). "L'avoir en travers...». La belle-mère, l'enfant et la guligir: rituel sans paroles à Samarcande. Études mongoles et sibériennes, centrasiatiques et tibétaines, (40).

[4] Firth, J.R. (1957). Papers in Linguistics. London: Oxford University Press.

[5] Fishman, J.A (1989). Language and Ethnicity in Minority Sociolinguistic Perspective. Clevedon: Multilingualm Matters.

[6] Glaser, B., \& Strauss, A. (1967). The discovery grounded theory: strategies for qualitative inquiry. Aldin, Chicago.
[7] Grosjean, F. (1982). Life with two Languages: An Introduction to Bilingualism. Cambridge, Mass: Harvard University Press.

[8] Kramsch, C. (1998). Language and Culture. Oxford University Press. New York.

[9] Lacoste-Dujardin, C. (1985). Des mères contre les femmes: maternité et patriarcat au Maghreb. Paris. La Découverte.

[10] Malinoswky, B. (1935). "The Real Linguistic Fact is the Full Utterance within its Context of Situation." In Pride, J.B. (1971). The Social Meaning of Language. London: Oxford University Press. (eds.).

[11] Naamane-Guessous, S. (2007). Au-delà de toute pudeur: la sexualité féminine au Maroc: conclusion d'une enquête sociologique menée de 1981 à 1984 à Casablanca. Eddif.

[12] Paillé, P. (1994). L’analyse par théorisation ancrée. Cahiers de recherche sociologique, (23), 147-181.

[13] Larrivée, P. (2003). Linguistic conflict and language laws: understanding the Quebec question. Macmillan.

[14] Rocher, G. (1968). Introduction à la sociologie générale. La Salle: Hurtubise. 3 Vol.

[15] Webb, B. (2001). Culturally Diverse Parent Child and Family Relationships. New York: Columbia University Press.

[16] Winnicott, D. W. (2006). La mère suffisamment bonne. Payot, coll. "Petite Bibliothèque Payot". 